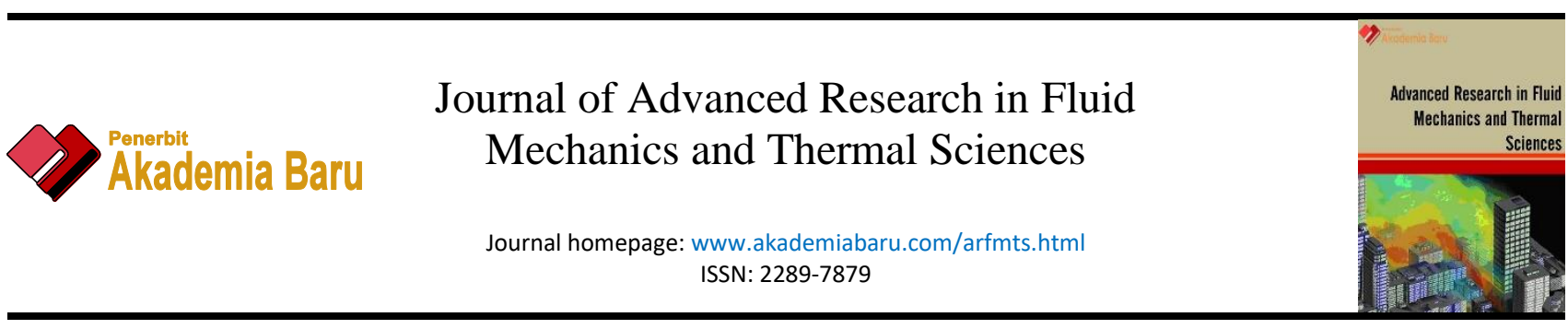

\title{
Effect of a New Absorber Design on the Performance of PV/T Collector: Numerical Comparative Study
}

\author{
Fadhil Abdulameer Sachit ${ }^{1,3,}$, , Mohd Afzanizam Mohd Rosli ${ }^{1,2}$, Noreffendy Tamaldin ${ }^{1,2}$, Suhaimi \\ Misha $^{1,2}$, Amira Lateef Abdullah ${ }^{1,3}$ \\ Fakulti Kejuruteraan Mekanikal, Universiti Teknikal Malaysia Melaka, Hang Tuah Jaya, 76100 Durian Tunggal, Melaka, Malaysia \\ 2 Centre for Advanced Research on Energy, Universiti Teknikal Malaysia Melaka, Hang Tuah Jaya, 76100 Durian Tunggal, Melaka, Malaysia \\ Ministry of Electricity, Baghdad, Republic of Iraq
}

\section{ARTICLE INFO}

\section{Article history:}

Received 27 January 2020

Received in revised form 3 April 2020

Accepted 9 April 2020

Available online 30 April 2020

\section{Keywords:}

Solar energy; Photovoltaic thermal collector; PV/T performance; Absorber design; Mass flow rate

\section{ABSTRACT}

The solar energy applications can be roughly divided into two main groups. A photovoltaic is an energy system that transforms solar energy into electric power and thermal energy system called solar collector that transforms solar energy into thermal energy. The photovoltaics performance affected by the high temperature of it is surface that absorbs the solar irradiance and the efficiency drop due to these higher temperatures. Therefore, the two systems associated with each other in the combined system called PV/T to enhance photovoltaic efficiency. The term PV/T (photovoltaic thermal) refers to a solar collector that uses a photovoltaic cell as an integral component of the absorption plate. The high temperature of solar photovoltaic will be decreased and transmitted to the circulated fluid inside the collector tubes. This system produces electrical and thermal at the same time. The solar collector is the vital part of PV/T. Many absorber designs have been developed in the solar collector to enhance the overall performance of the PV/T system. In the present work, a new photovoltaic thermal collector named serpen-direct is designed. Modeling for the new absorber design has been developed and validated. Numerically, PV/T performance for the serpent-direct design is analyzed and compared with the conventional serpentine design by using MATLAB Simulink. The PV and thermal efficiencies were determined under various parameters condition; mass flow rates range from $0.01 \mathrm{~kg} / \mathrm{s}$ to $0.1 \mathrm{~kg} / \mathrm{s}$ and solar irradiance values $700 \mathrm{~W} / \mathrm{m} 2$ and $900 \mathrm{~W} / \mathrm{m} 2$. Results indicate that the serpendirect flow absorber design achieved a better system overall performance than serpentine design under similar operating conditions. The higher electrical and thermal efficiencies were $14.52 \%, 55 \%$, respectively, for the PV/T serpen-direct absorber design and $14.43 \%, 56.1 \%$, correspondingly, for the serpentine absorber design.

Copyright $@ 2020$ PENERBIT AKADEMIA BARU - All rights reserved

\footnotetext{
${ }^{*}$ Corresponding author.

E-mail address: fatj_1983@yahoo.com (Fadhil Abdulameer Sachit)
}

https://doi.org/10.37934/arfmts.71.1.6071 


\section{Introduction}

The hybrid PV/T system shown in Figure 1 is a technology that transforms solar radiation, simultaneously, into heat and electricity. This system Combine the functions of the photovoltaics and solar collectors [1]. It consists of adding a solar collector under the photovoltaic module. An absorber plate contact with the photovoltaic. In this way, the absorber plate will collect the thermal energy causing in the photovoltaic module, which results in an improvement in the electric production. This thermal energy uses to heat water or air circulating in the solar absorber [2].

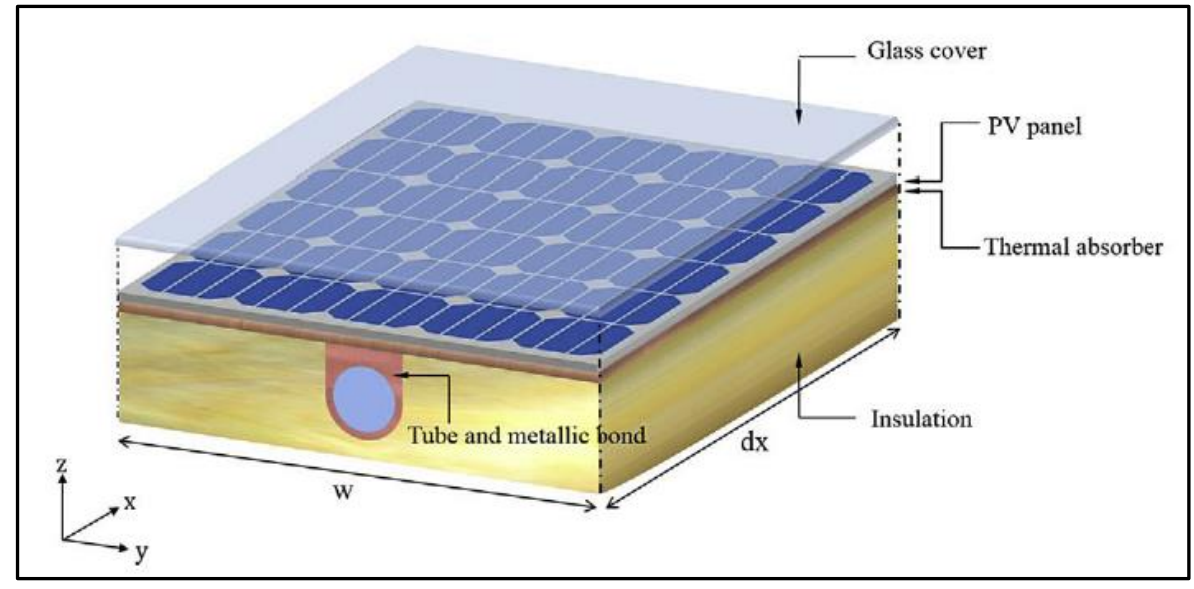

Fig. 1. Photovoltaic thermal system [1]

The main advantages of the hybrid photovoltaic thermal system are:

i. This type of system generates a greater amount of thermal and electrical energy per $\mathrm{m} 2$ than a separate system (thermal + photovoltaic). Therefore, it is particularly useful in situations where the roof area is reduced.

ii. Improve the efficiency of the photovoltaic panel.

iii. Because only one type of system is installed, rather than two, a saving in installation expenses is possible [3].

Many correlations express the temperature of the photovoltaic cell depending on climatic conditions, such as solar irradiance, ambient temperature, and wind speed. Other parameters that influence the electrical efficiency are the materials used in the system, such as the transmittance of glass roofs, the absorber plate, etc. Also, this electrical efficiency depends heavily on the solar irradiance flux over the PV panel and the type of PV module. A commercial photovoltaic module can convert from 6 to $20 \%$ of incident solar irradiance into electrical energy. Part of solar irradiance is reflected, but the remain of the absorbed solar irradiance is converted to heat, that accordingly due to the increase in the temperature of photovoltaic and reduce its efficiency. This heat extract by running water or air, moving in the back of the module, making use of thermal collectors [4].

From above, many technics have been used to develop the PV/T system to enhance photovoltaic performance. Several studies have been presented depend on a different type of PV panel [5], the type of circulating fluid (Colling medium) [6] and the absorber design of solar collector [7-8].

In the following literature will be a focus on the development of a PV/T system performance based on the development of the flow absorber design. The flow absorber design depends on the configurations of tubes under the absorber plate.

Ibrahim et al., [9] have been studied the effect of several absorber designs shown in Figure 2 on the PV/T overall performance. They are using a simulation that conducted based on different parameters condition, such as, ambient temperature, mass flow rate and solar irradiance to 
determine the best absorber design with the highest electrical and thermal efficiency. The Results indicate that the spiral flow absorber design has been achieved the highest performance with thermal (50.12\%) and electrical (11.98\%).

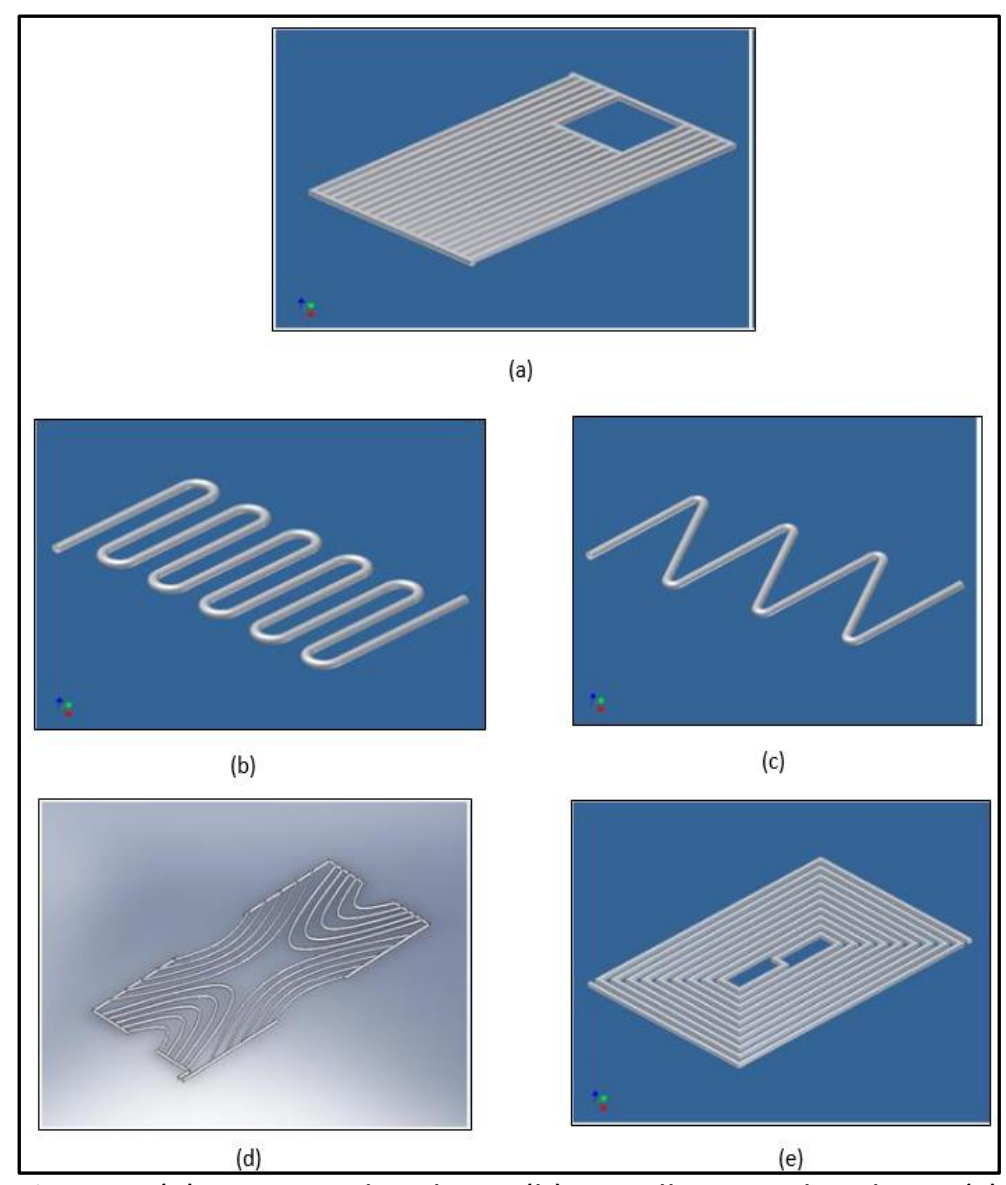

Fig. 2. (a) Direct absorber, (b) Oscillatory absorber, (c) Serpentine absorber, (d) Web absorber, (e) Spiral absorber [9]

An experimental study has been conducted for a new absorber design to predict the PV/T overall performance [10]. The plate and tube solar collector are integrated with a PV panel. The new absorber design has been found as simple in manufacturing compared with the other designs.

In the same direction of research, Sardouei et al., [11] have been studied numerically and experimentally for different designs of PV/T solar collector. They are using CFD approach (computational fluid dynamic) to simulate the model. Experimental work was conducted to validate the results. The measurements determined under the low range of mass flow rate. The findings indicate that direct flow absorber achieved the highest temperature gradient. The results revealed that the uniform temperature distribution increases the overall performance of the PV/T. The experimental studies get more interesting from the researchers to develop the PV/T performance with new collector design. With different idea named (heat pipe pulsating) a novel PV/T design have been presented [12]. The study takes into account several parameters, such as mass flow rate, ambient temperature, solar irradiance, and inlet temperature. The results revealed to good thermal and electrical efficiencies compared with the conventional systems (PV/T and photovoltaic).

Furthermore, by using CFD approach simulation and experimental work, Zhou et al., [13] have been investigating the distribution temperature in $\mathrm{PV} / \mathrm{T}$ collector with serpentine absorber design. They studied the impact of parameters condition on the temperature distribution of PV/T surface, 
such as absorber materials, tube configuration arrangement, and spacing tube. The results have been found that the uniform distribution temperature has more affected on the PV/T performance.

The literature Above mentioned that absorber design in PV/T system has an impact on its performance. Also, the literature showed that the mechanism of the heat transfers in the PV/T system deepened mainly on the configurations of the tubes in the flow absorber design. Based on this issue, the different PV/T absorber designs have some disadvantages such as, non-uniform distribution temperatures, low thermal efficiency and low electrical efficiency.

The developing of the new absorber design with new configuration of tubes will be improve the heat transfer mechanism between the PV module and solar collector in PV/T system. That will be overcome the problem of the non-uniform temperature of the PV surface. Meanwhile, improve the overall performance of the PV/T system.

This paper presents a report on the validation of modeling for the new absorber design in PV/T solar system named the "serpen-direct flow" as illustrated in Figure 3. The performance of the new absorber design has been analyzed and compared with the conventional serpentine absorber design under different parameters condition (solar irradiance and water mass flow rate). The thermal and electrical analysis was satisfied to evaluate the electrical and thermal efficiencies for the twoabsorber design, MATLAB Simulink has been used for this purpose.

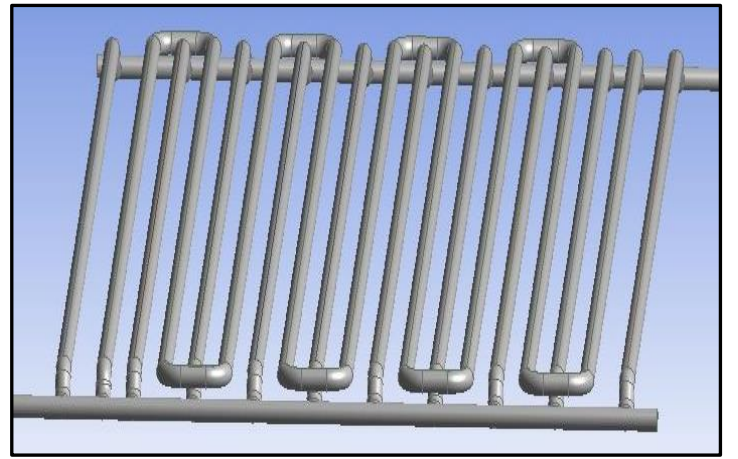

(a)

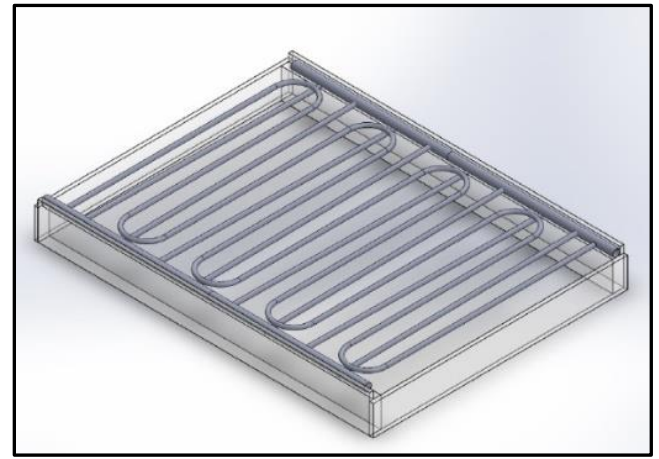

(b)

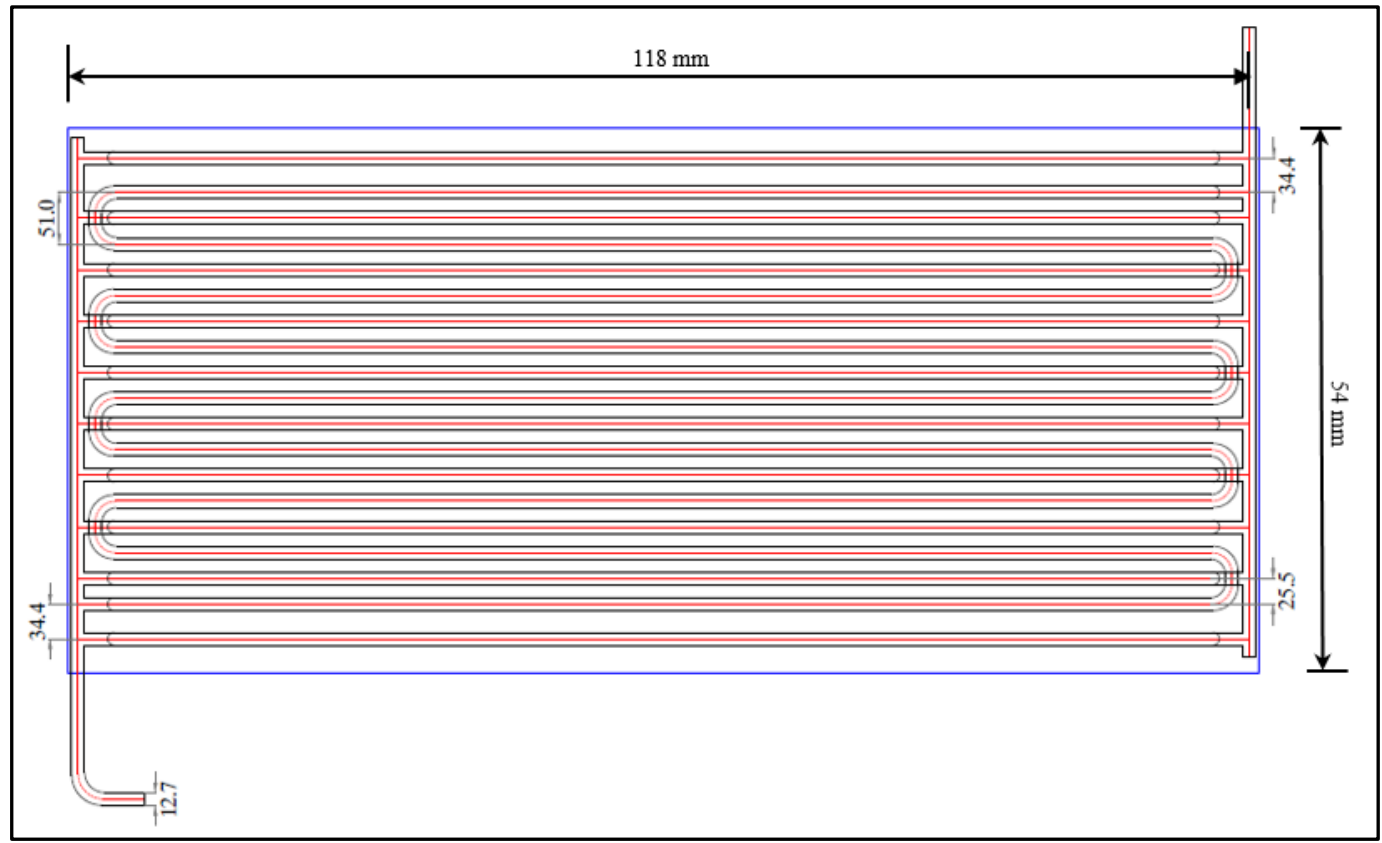

(c)

Fig. 3. Serpen-direct absorber design (a) Front view, (b) 3D diagram, (c) Front view with dimensions 


\section{Methodology}

A Simulink by using Matlab as shown in Figure 4 conducted to calculate the PV/T performance for the new absorber design (serpen-direct) and the serpentine design based on the design parameters lists in Table 1. The mathematical model of the serpen-direct PV/T absorber design has been developed based on the new configurations of the serpen-direct flow absorber design that illustrated in Figure 3. Also, the thermal and electrical performance expressions of PV/T performance can be written as illustrated in the following subsections.

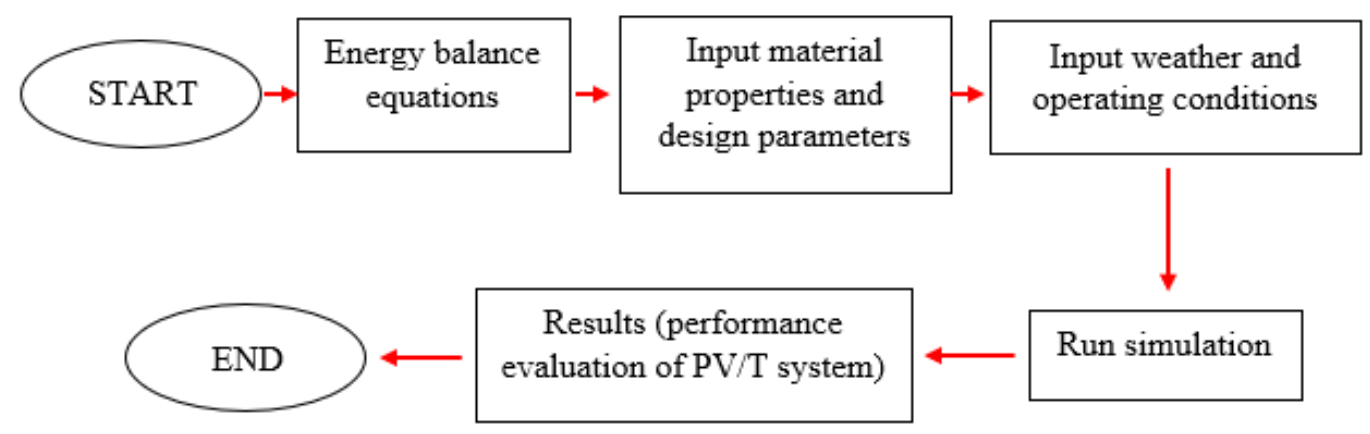

Fig. 4. Flowchart of the Matlab Simulink for the PV/T system performance evaluation

Table 1

\begin{tabular}{ll} 
PV/T parameters & \\
\hline Parameters & Values (unit) \\
\hline Collector area & $0.6372 \mathrm{~m}^{2}$ \\
Tube diameter & $0.0127 \mathrm{~m}$ \\
Specific heat of the water & $4180 \mathrm{~J} / \mathrm{kg}^{\circ} \mathrm{C}$ \\
Absorber material & Copper \\
Insulation material & Polystyrene \\
Back insulation thickness & $0.036 \mathrm{~m}$ \\
Tubes material & Copper \\
Absorber plate thermal conductivity & $385 \mathrm{~W} / \mathrm{m}^{\circ} \mathrm{C}$ \\
Absorber plate thickness & $0.0015 \mathrm{~m}$ \\
Absorber transmittivity & 0.88 \\
Absorber absorptivity & 0.95 \\
Photovoltaic module type & Monocrystalline \\
Photovoltaic reference efficiency & 15.5 \\
Solar cell size & $0.125 \mathrm{~m} \times 0.125 \mathrm{~m}$ \\
$\boldsymbol{I}_{\boldsymbol{s c}}$ & $6.11 \mathrm{~A}$ \\
$\boldsymbol{V}_{\boldsymbol{o c}}$ & $21.6 \mathrm{~V}$ \\
$\boldsymbol{I}_{\text {max }}$ & $5.55 \mathrm{~A}$ \\
$\boldsymbol{V}_{\text {max }}$ & $18 \mathrm{~V}$ \\
Max power PV & $100 \mathrm{~W}$ \\
\hline
\end{tabular}

\subsection{Thermal Performance of the PV/T System}

The thermal output performance of the PV/T system can be referred to as the ratio of useful energy gain over the solar irradiance per unit area at the same instant [14-15].

$\eta_{\text {thermal }}=\frac{\int Q_{u} d t}{A_{c} \int I(t) d t}$ 
where $A_{c}$ is the area of collector, $I(t)$ is the solar irradiance and $Q_{u}$ is the useful heat gain, that can be expressed as follows:

$Q_{u}=A_{c} F_{r}\left[(\alpha \tau)_{n} \cdot I(t)-U_{L}\left(T_{f i}-T_{a}\right)\right]$

where $(\alpha \tau)_{n}$ is the $\mathrm{PV} / \mathrm{T}$ system transmittance absorptance product, $U_{L}$ is the overall losses coefficient , $T_{f i}$ is the inlet water temperature, $T_{a}$ is the ambient temperature and $F_{r}$ is the removal factor of the collector, can be expression as follows [16-17].

$F_{r}=\frac{m_{f} C_{f}}{A_{c} U_{L}} \times\left[1-\exp \left(-\frac{A_{c} U_{L} F^{\prime}}{m_{f} C_{f}}\right)\right]$

where $m_{f}$ is the water mass flow rate, $C_{f}$ is the heat capacity of water and $F^{\prime}$ is the effectiveness factor of the collector in PV/T system.

\subsection{Photovoltaic Module Efficiency of the PV/T System}

The PV efficiency of the PV/T collector primarily depends on the cell temperature as illustrated in the following equation [18-19].

$\eta_{P V}=\eta_{c}\left[1-0.0045\left(T_{c}-T_{r e f}\right)\right]$

where $T_{\text {ref }}$ is the reference temperature and $T_{c}$ is the cell temperature and $\eta_{c}$ is the reference efficiency of the PV module.

\subsection{Modelling Development of the PV/T System for the New Serpen-direct Flow Absorber Design}

Figure 3 shows that the combination of two sets of parallel tubes (direct and serpentine) directly modifies the area of new absorber design (serpen-direct) absorber design of PV/T system. The solar collector area is an important element in the evaluations of thermal energy and heat removal factor as revealed in Eq. (2)-(3). These expressions were modified according to the area of serpen-direct flow absorber design. The area of solar collector for different absorber designs was calculated as follows [14]:

$A_{c-\text { serpentine }}=L \times W \times N S$

$A_{c-\text { direct }}=L \times W$

where $\mathrm{L}, \mathrm{W}$ is the length and width of the collector, respectively, NS is the number of tubes segment in the serpentine configurations. Therefore, $F_{r}, Q_{u}$ and $\eta_{\text {thermal }}$ can be expressed as follows,

Removal factor for serpen-direct flow absorber design:

$F_{r}$ will be calculated as, $F_{r-\text { serpentine }}$ determined as in [20-21] based on $A_{c-\text { serpentine }}$ calculation, and $F_{r-\text { direct }}$ can be evaluate as in Eq. (3),

$F_{r \text { serpen-direct }}=\frac{F_{r-\text { serpentine }}+F_{r-\text { direct }}}{2}$ 
Thermal energy gains for serpen-direct flow absorber design:

The thermal energy for serpen-direct absorber $Q_{u}$ will be written as,

$Q_{u \text { serpen-direct }}=A_{c} F_{r \text { serpen-direct }}\left[(\alpha \tau)_{n} \cdot I(t)-U_{L}\left(T_{f i}-T_{a}\right)\right]$

Thermal performance for serpen-direct flow absorber design:

The thermal efficiency of the PV/T serpen-direct flow absorber design can be evaluated as,

$\eta_{\text {thermal,Serpin-Direct }}=\frac{\int Q_{u \text { serpen-direct }} d t}{A_{c} \int I(t) d t}$

\section{Results and Discussion}

This section presents the analyzing of the PV/T overall performance in term of electrical and thermal efficiencies for both absorber designs (serpen-direct and serpentine). The performance has been investigated under different parameters condition, such as solar irradiance and water mass flow rate. The new model of $\mathrm{PV} / \mathrm{T}$ serpen-direct has also been verified in the following section.

\subsection{Model Validation}

To verify the new absorber design for PV/T system (serpen-direct), we use the data collected in the previous study of Zhou et al., [13] to compare the existing simulation results at the same input data with the simulation results from the previous study. The electrical values have been compared at the same operating conditions to validate the existing work Matlab Simulink (author simulation).

Figure 5 shows the difference in electrical efficiency between the simulation of the existing work and the results of previous work simulation [13] does not exceed $6.1 \%$, the minimum percentage difference is $0.2 \%$, and the root mean square value is $1.45 \%$. Therefore, the results indicate the good agreement.

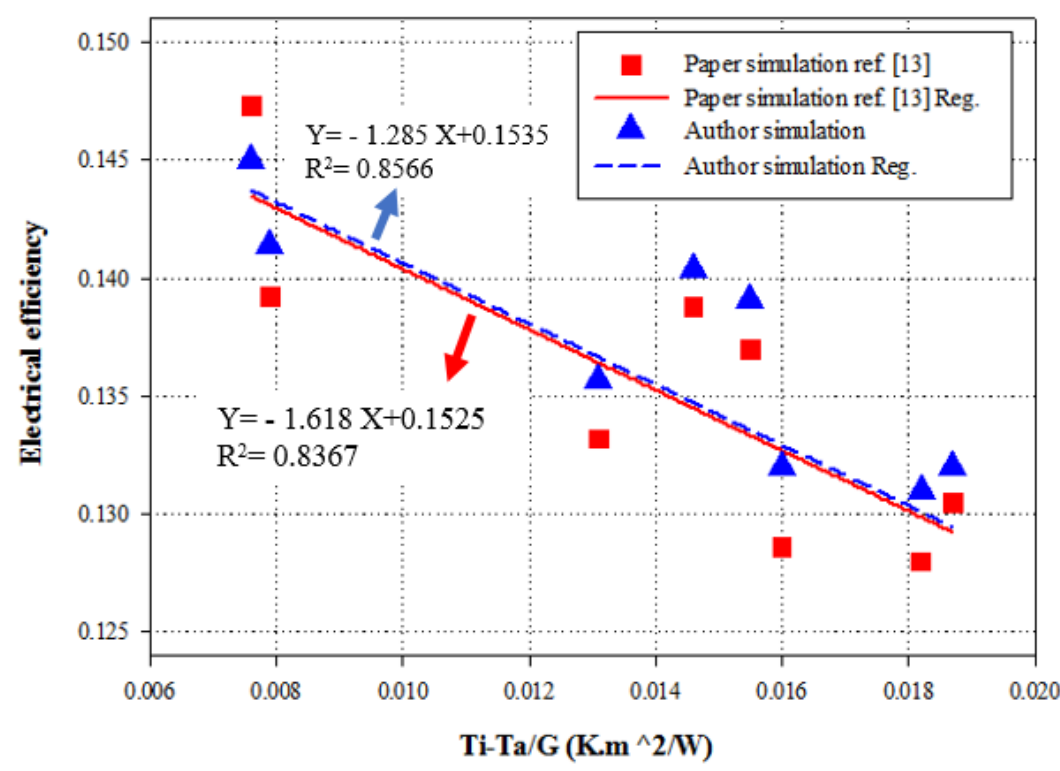

Fig. 5. Comparison of simulation results for electrical efficiency according to the reduced temperature between the previous study and the Author work 


\subsection{Effects of Mass Flow Rate and Solar Irradiance on Thermal Efficiency of the PV/T System}

The mass flow rate greatly affects the thermal efficiency of the PV/T system. This section discussed the effect of various mass flow rates of water on the thermal efficiency of both (serpendirect and serpentine) flow absorber designs. Figure 6 compares the difference in thermal efficiency between the two designs with the increase in water flow rate at $700 \mathrm{~W} / \mathrm{m} 2$. The thermal efficiency of both absorber designs increases with increasing mass flow rate, taking into account the relative relationship between water flow rate and thermal efficiency as specified in Eq. (1)-(2).

In Figure 6 and Figure 7 by increasing the solar irradiance from $700 \mathrm{~W} / \mathrm{m} 2$ to $900 \mathrm{~W} / \mathrm{m} 2$ with same mass flow rate, the thermal efficiency increases for both absorber design (serpentine and serpen-direct). It can be noted that at $0.012 \mathrm{~kg} / \mathrm{s}$ in Figure 6 the thermal efficiencies were $50 \%$ and $49.5 \%$ for serpen-direct and serpentine absorber, respectively. After that, with $0.058 \mathrm{~kg} / \mathrm{s} \mathrm{mass} \mathrm{flow}$ rate the thermal efficiencies increase to achieved $52.2 \%$ and $53.5 \%$ for the serpen-direct and serpentine absorber, correspondingly. Also, it can be noted that there is no significant change in the description of the effect of the mass flow rate of thermal efficiency in Figure 7, including solar irradiance of $900 \mathrm{~W} / \mathrm{m} 2$. Furthermore, it can be seen that the thermal efficiency is higher in a serpentine flow design than in a serpen-direct flow design with a mass flow rate greater than 0.012 $\mathrm{kg} / \mathrm{s}$.

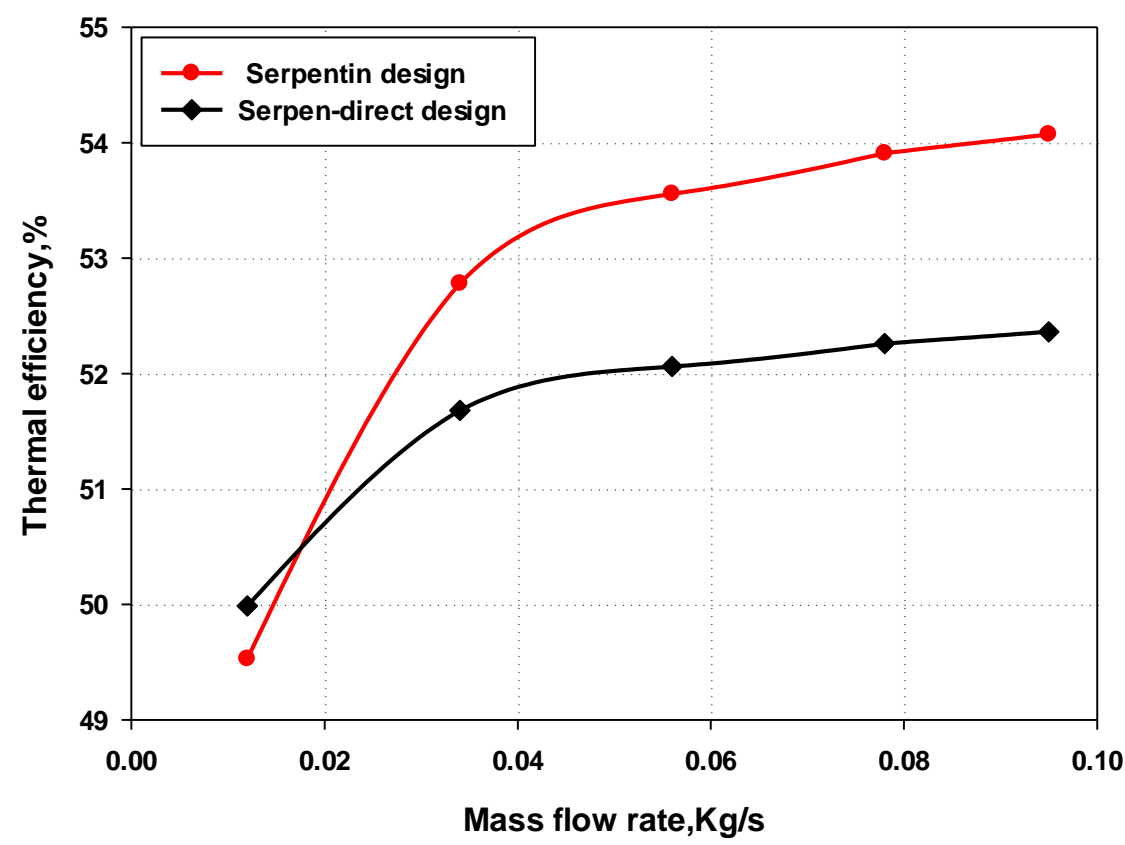

Fig. 6. Effects of mass flow rate variation on thermal efficiency at solar irradiance $700 \mathrm{~W} / \mathrm{m} 2$ 


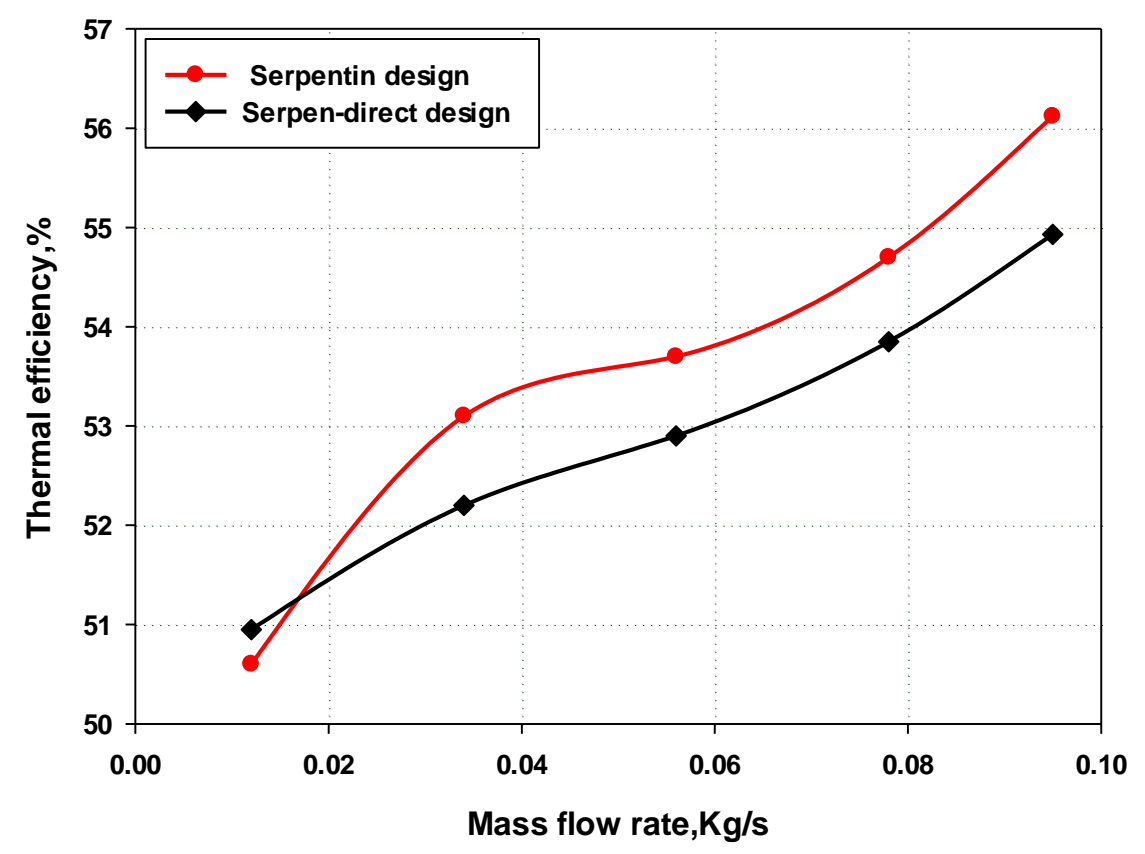

Fig. 7. Effects of mass flow rate variation on thermal efficiency at solar irradiance $900 \mathrm{~W} / \mathrm{m} 2$

\subsection{Effects of Mass Flow Rate and Solar Irradiance on the PV Efficiency of the PV/T System}

The effect of mass flow rate on photovoltaic efficiency related to solar cell temperature. The temperature of the PV surface decreases as the mass flow rate increases. That led to a direct impact on PV efficiency as expressed in Eq. (4).

Figure 8 shows the photovoltaic efficiencies at different mass flow rates and $700 \mathrm{~W} / \mathrm{m} 2$ solar irradiance. The results show that the PV efficiency of two design increases with increasing mass flow rate. The PV module efficiency achieved $14.37 \%$ and $14.31 \%$ for PV/T serpen-direct and serpentine flow absorber, respectively, with a flow rate of $0.012 \mathrm{~kg} / \mathrm{s}$. Besides, the PV efficiencies at mass flow rates increasing from $0.012 \mathrm{~kg} / \mathrm{s}$ to $0.058 \mathrm{~kg} / \mathrm{s}$ were $14.47 \%$ and $14.42 \%$, respectively, for the PV/T serpen-direct and serpentine flow absorber.

In the results in Figure 9 show that the photovoltaic efficiency values are $13.37 \%$ and $13.84 \%$ for $\mathrm{PV} / \mathrm{T}$ serpentine and serpen-direct absorber, respectively, with $0.012 \mathrm{~kg} / \mathrm{s}$ and $900 \mathrm{~W} / \mathrm{m} 2$, respectively. Also, as the water flow rate increases to $0.058 \mathrm{~kg} / \mathrm{s}$, the $\mathrm{PV} / \mathrm{T}$ serpentine and serpendirect absorber photovoltaic efficiency increase by $13.78 \%$ and $14.18 \%$, respectively. These results indicate that PV efficiency in serpen-direct design higher than serpentine design.

From the above, it is obvious two facts, firstly that photovoltaic efficiency increased with mass flow rate increase because of the increase in the heat transfer between the solar panel and the circulating water inside the tubes of solar collector. Secondly, that the PV efficiency drops with higher solar irradiance due to higher cell temperature obtained with higher solar irradiance. 


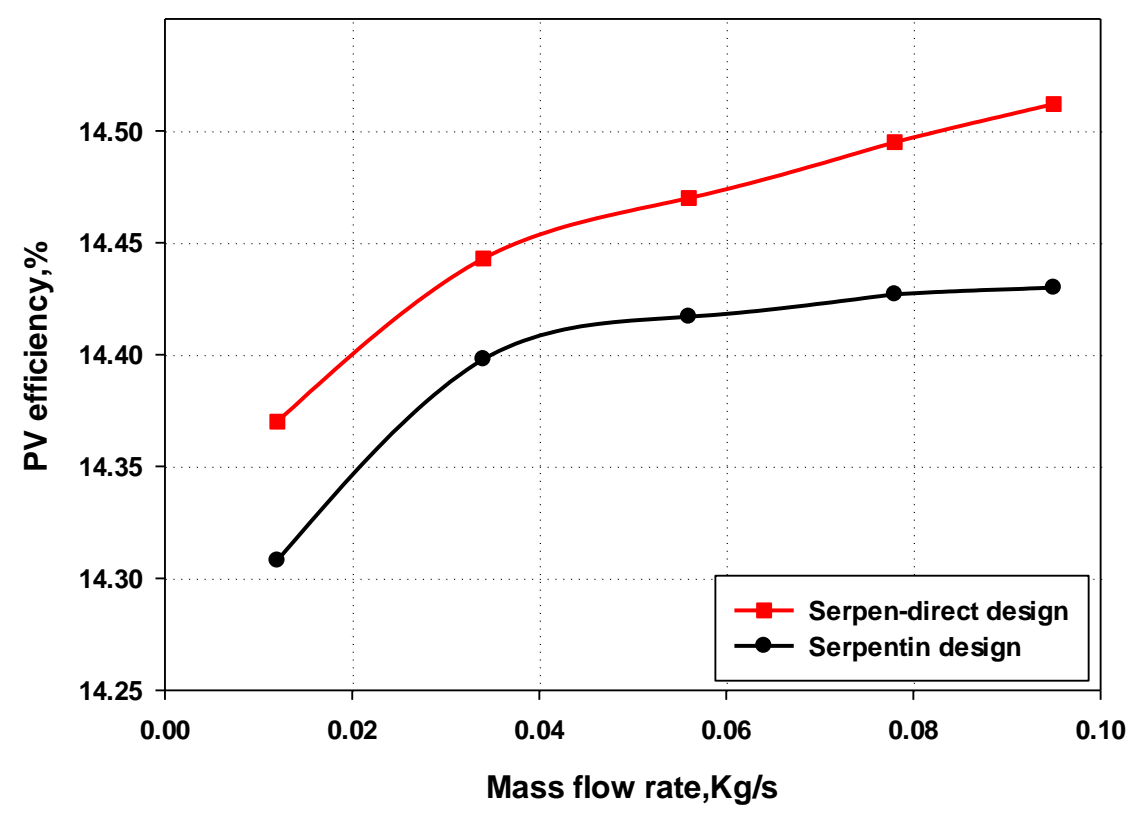

Fig. 8. Effects of mass flow rate variation on PV efficiency at solar irradiance $700 \mathrm{~W} / \mathrm{m} 2$

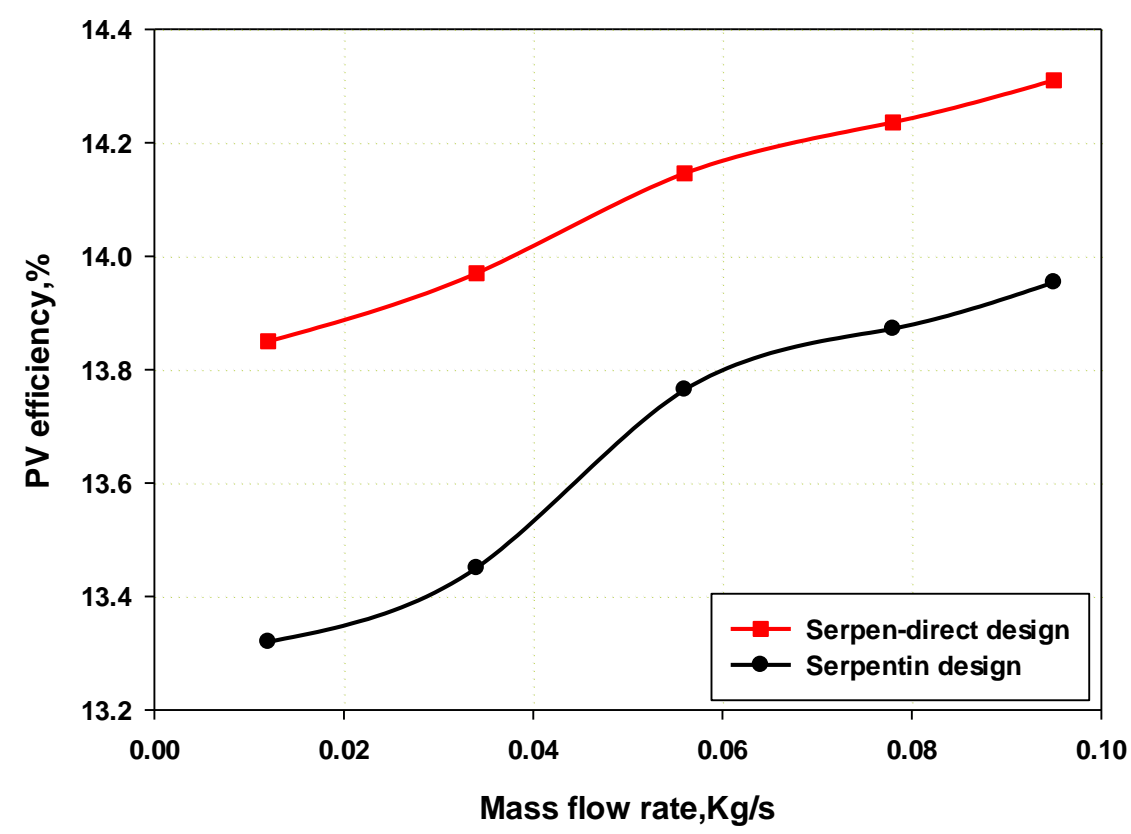

Fig. 9. Effects of mass flow rate variation on PV efficiency at solar irradiance $900 \mathrm{~W} / \mathrm{m} 2$

\section{Conclusions}

The performance of the PV/T system was determined based on various absorber designs, and a comparative study of system performance was performed. The results showed that the performance of the PV/T collector could be improved by increasing the mass flow rate of water. The maximum efficiency of photovoltaic is $14.52 \%$ and $14.43 \%$, respectively, with a flow rate of $0.098 \mathrm{~kg} / \mathrm{s}$ and solar radiation of $700 \mathrm{~W} / \mathrm{m} 2$, respectively. Also, at optimized parameters condition, mass flow rate 0.012 $\mathrm{kg} / \mathrm{s}$ and $900 \mathrm{~W} / \mathrm{m} 2$ solar radiation, the thermal performance of both PV/T designs serpen-direct and serpentine were found $51 \%$ and $50.7 \%$, correspondingly. These results show that serpen-direct flow absorber design works better than serpentine absorber in PV/T systems. 


\section{Acknowledgement}

This work was funded by Universiti Teknikal Malaysia Melaka (Grant No. FRGS/1/2018/TK07/UTEM/02/4). The authors would like to thank the Fakulti Kejuruteraan Mekanikal of the Universiti Teknikal Malaysia Melaka for the registration fee support to participate in ICESEAM2019, Centre for Advanced Research on Energy in Universiti Teknikal Malaysia Melaka and Ministry of Electricity in Iraq for supporting this work

\section{References}

[1] Yazdanifard, Farideh, Ehsan Ebrahimnia-Bajestan, and Mehran Ameri. "Investigating the performance of a waterbased photovoltaic/thermal (PV/T) collector in laminar and turbulent flow regime." Renewable Energy 99 (2016): 295-306. https://doi.org/10.1016/i.renene.2016.07.004

[2] Zondag, H. A., D. W. De Vries, W. G. J. Van Helden, R. J. C. Van Zolingen, and A. A. Van Steenhoven. "The yield of different combined PV-thermal collector designs." Solar Energy 74, no. 3 (2003): 253-269.

https://doi.org/10.1016/S0038-092X(03)00121-X

[3] De Vries, D. Wiebe. "Design of a photovoltaic/thermal combi-panel." PhD report, EUT (1998).

[4] Satpute, Jitendra B., and John A. Rajan. "Recent advancement in cooling technologies of solar photovoltaic (PV) system." FME Transactions 46, no. 4 (2018): 575-584. https://doi.org/10.5937/fmet1804575S

[5] Tripanagnostopoulos, Yiannis, T. H. Nousia, M. Souliotis, and P. Yianoulis. "Hybrid photovoltaic/thermal solar systems." Solar Energy 72, no. 3 (2002): 217-234.

https://doi.org/10.1016/S0038-092X(01)00096-2

[6] Siecker, J., K. Kusakana, and B. P. Numbi. "A review of solar photovoltaic systems cooling technologies." Renewable and Sustainable Energy Reviews 79 (2017): 192-203.

https://doi.org/10.1016/i.rser.2017.05.053

[7] Sachit, F. A., Noreffendy Tamaldin, M. A. M. Rosli, S. Misha, and A. L. Abdullah. "Current progress on flat-plate water collector design in photovoltaic thermal (PV/T) systems: A Review." Journal of Advanced Research in Dynamical and Control Systems 10, no. 4 (2018): 680-694.

[8] Rosli, Mohd Afzanizam Mohd, Yap Joon Ping, Suhaimi Misha, Mohd Zaid Akop, Kamaruzzaman Sopian, Sohif Mat, Ali Najah Al-Shamani, and Muhammad Asraf Saruni. "Simulation study of computational fluid dynamics on photovoltaic thermal water collector with different designs of absorber tube." Journal of Advanced Research in Fluid Mechanics and Thermal Sciences 52, no. 1 (2018): 12-22.

[9] Ibrahim, Adnan, Mohd Yusof Othman, Mohd Hafidz Ruslan, M. Alghoul, M. Yahya, Azami Zaharim, and Kamaruzzaman Sopian. "Performance of photovoltaic thermal collector (PVT) with different absorbers design." WSEAS Transactions on Environment and Development 5, no. 3 (2009): 321-330.

[10] Touafek, K., A. Khelifa, M. Adouane, E. H. Khettaf, and A. Embarek. "Experimental study on a new conception of hybrid PV/T collector." In 14th International Conference on Sciences and Techniques of Automatic Control \& Computer Engineering-STA'2013, pp. 140-145. IEEE, 2013.

https://doi.org/10.1109/STA.2013.6783120

[11] Sardouei, Masoud Mohammadi, Hamid Mortezapour, and Kazem Jafari Naeimi. "Temperature distribution and efficiency assessment of different PVT water collector designs." Sādhanā 43, no. 6 (2018): 84. https://doi.org/10.1007/s12046-018-0826-x

[12] Balotaki, Hassan Kavoosi, and Mohammad Hassan Saidi. "Design and Performance of a Novel Hybrid PhotovoltaicThermal Collector with Pulsating Heat Pipe (PVTPHP)." Iranian Journal of Science and Technology, Transactions of Mechanical Engineering 43, no. 1 (2019): 371-381.

https://doi.org/10.1007/s40997-018-0164-y

[13] Zhou, Jicheng, Haoyun Ke, and Xiaoqing Deng. "Experimental and CFD investigation on temperature distribution of a serpentine tube type photovoltaic/thermal collector." Solar Energy 174, no. 3 (2018): 735-742. https://doi.org/10.1016/j.solener.2018.09.063

[14] Duffie, John A., and William A. Beckman. Solar Engineering of Thermal Processes, Fourth Edition. John Wiley \& Sons, 2013.

https://doi.org/10.1002/9781118671603

[15] Hottel, Hoyte, and Austin Whillier. "Evaluation of Flat-Plate Collector Performance." In Transactions of the Conference on the Use of Solar Energy, pp. 74-104. University of Arizona Press, 1958.

[16] Vokas, G., N. Christandonis, and F. Skittides. "Hybrid photovoltaic-thermal systems for domestic heating and 
cooling-a theoretical approach." Solar Energy 80, no. 5 (2006): 607-615.

https://doi.org/10.1016/i.solener.2005.03.011

[17] Moreno, David, Manuel Fernández, and Paula M. Esquivias. "A comparison of closed-form and finite-element solutions for heat transfer in a nearly horizontal, unglazed flat plate PVT water collector: Performance assessment." Solar Energy 141 (2017): 11-24.

https://doi.org/10.1016/i.solener.2016.11.015

[18] Florschuetz, L. W. "Extension of the Hottel-Whillier model to the analysis of combined photovoltaic/thermal flat plate collectors." Solar Energy 22, no. 4 (1979): 361-366.

https://doi.org/10.1016/0038-092X(79)90190-7

[19] Evans, D. L. "Simplified method for predicting photovoltaic array output." Solar Energy 27, no. 6 (1981): 555-560. https://doi.org/10.1016/0038-092X(81)90051-7

[20] Rosli, M. A. M., Suhaimi Misha, Kamaruzzaman Sopian, Sohif Mat, Mohd Yusof Sulaiman, and Elias Salleh. "Thermal Efficiency of the Photovoltaic Thermal System with Serpentine Tube Collector." In Applied Mechanics and Materials, vol. 699, pp. 455-461. Trans Tech Publications Ltd, 2015.

https://doi.org/10.4028/www.scientific.net/AMM.699.455

[21] Abdel-Khalik, S. I. "Heat removal factor for a flat-plate solar collector with a serpentine tube." Solar Energy 18, no. 1 (1976): 59-64.

https://doi.org/10.1016/0038-092X(76)90036-0 